\title{
Prey of the Antarctic fur seal Arctocephalus gazella at Marion Island
}

\author{
A. B. Makhado ${ }^{1,5}$, M. N. Bester ${ }^{1}$, S. P. Kirkman ${ }^{4}$, P. A. Pistorius ${ }^{1}$, \\ J. W. H. Ferguson ${ }^{1,2}$ and N. T. W. Klages ${ }^{3}$
}

(1) Mammal Research Institute, Department of Zoology and Entomology, University of Pretoria, Pretoria, 0002, South Africa

(2) Centre for Environmental Studies, Department of Zoology and Entomology, University of Pretoria, Pretoria, 0002, South Africa

(3) Institute for Environmental and Coastal Management, University of Port Elizabeth, P.O. Box 1600, Port Elizabeth, 6000, South Africa

(4) Avian Demography Unit, Department of Statistical Sciences, University of Cape Town, Rondebosch, 7701, South Africa

(5) Department of Environmental Affairs and Tourism, Branch Marine and Coastal Management, Private Bag X2, Rogge Bay, 8012, South Africa

\author{
A. B. Makhado \\ Email: Amakhado@deat.gov.za
}

\section{Abstract}

The prey of Antarctic fur seals, Arctocephalus gazella, was investigated through scat analysis at Marion Island from 1996 until 2000. A total of 25 different prey species were identified from scats, of which 21 were fish, 1 crustacean and 3 cephalopods. Fish were by far the main prey item, occurring in $96.1 \%$ of samples, followed by crustaceans $(2.7 \%)$ and cephalopods (1.2\%). Fishes from the family Myctophidae (Gymnoscopelus piabilis, Electrona carlsbergi, G. fraseri and E. subaspera) were the most abundant prey (97.2\%) every year, while those from the families Notothenididae, Paralepididae, Notosudidae, Microstomatidae and Gempylidae were present in small numbers. $G$. piabilis, E. carlsbergi, E. subaspera and G. nicholsi contributed the most in terms of biomass to the diet. Significant seasonal differences existed in the diet when comparing summer and winter. G. piabilis, $K$. anderssoni, $P$. bolini and $P$. choriodon dominated in summer as opposed to E. carlsbergi, E. subaspera, G. fraseri and G. nicholsi that dominated in winter. The fish varied in size and mass, from the small $K$. anderssoni to the large Paranotothenia magellanica. Cephalopods and the crustacean Nauticaris marionis, in very low numbers and in winter, appeared in the scats, but not in all years of study. Unidentified penguin remains rarely turned up in scats. 


\section{Introduction}

The Antarctic fur seal (Arctocephalus gazella) occur characteristically on islands to the south of the Antarctic Polar Front (APF), whereas the subAntarctic fur seal (A. tropicalis) typically breeds to the north of the APF (Bester 1984). However, the two species breed sympatrically at three localities just to the north of the APF, namely Macquarie Island (Goldsworthy 1999), Iles Crozet (Guinet et al. 1994) and the Prince Edward Archipelago (Condy 1978). The annual rate of growth of the Antarctic fur seal population at Marion Island (Prince Edward Archipelago) increased from about 11\% between 1981-1982 and 1988-1989 (Wilkinson and Bester 1990) to about $17 \%$ for the period 1988-1989 to 1994-1995 (Hofmeyr et al. 1997). Breeding occurs at ten sites on Marion Island; the largest breeding colony is found at Watertunnel Stream on the south coast. This colony accounted for $\square 90 \%$ of births in 1994-1995, or $n=\square 210$. The Antarctic fur seal population at Marion Island is outnumbered by the large, increasing population of subAntarctic fur seals, of which more than 10,000 pups were produced at numerous sites around Marion Island in 1994-1995 (Hofmeyr et al. 1997).

The feeding ecology of A. gazella has been studied at numerous locations throughout its range, namely South Georgia (Bonner 1968; North et al. 1983; North 1996; Reid 1995; Reid and Arnould 1996), Heard Island (Green et al. 1989, 1991, 1997)), the South Shetland Islands (Daneri 1996; Casaux et al. 1998; Daneri and Carlini 1999; Osman et al. 2004), the South Orkney Islands (Daneri and Coria 1992, 1993), Macquarie Island (Goldsworthy et al. 1997), Iles Kerguelen (Cherel et al. 1997; Lea et al. 2002a), Bouvet Island (Klages et al. 1999; Kirkman et al. 2000) and the Antarctic Peninsula (Casaux et al. 2003). Krill and various fish species constitute the bulk of the diet, with the relative importance of the different prey species varying with geographic location, season and the sex of individuals (Daneri and Carlini 1999).

Most studies on the diet of A. gazella were based on the analysis of scat samples, although stomach contents were also obtained from shot animals (Croxall and Pilcher 1984) and by stomach flushing (Reid and Arnould 1996). Only the hard remains (e.g. fish otoliths, bones, scales and eye lenses, cephalopod beaks and lenses, crustacean carapaces, etc.) are likely to be identified from scats (eg. Cherel et al. 1997). However, some hard parts are entirely digested and are reduced in size during the passage through the digestive tract (Pierce and Boyle 1991; Pierce et al. 1991; Klages and Bester 1998). Despite this and other biases inherent to the method (Dellinger and Trillmich 1988; Klages and Bester 1998), scat analysis provides the least intrusive method of investigating the diets of the fur seals (Pierce et al. 1991) and was the method of choice for this study.

The study of the foraging ecology and diet of the Antarctic fur seal have recently been intensified (this study; MRI unpublished data) under the Prince Edward Islands Pinniped Monitoring Programme. Although there have been two previous accounts of the diet composition of this species at Marion Island (Condy 1981; Klages and Bester 1998), none have addressed temporal variability in diet. The present study is aimed at 
investigating both interannual and seasonal variation in the diet composition of A. gazella over a period of 5 years (1996-2000).

\section{Materials and methods}

Scats were collected from the Watertunnel Stream colony of Antarctic fur seals at Marion Island $\left(46^{\circ} 54^{\prime} \mathrm{S}, 37^{\circ} 45^{\prime} \mathrm{E}\right)$ from May 1996 to April 2000, during bi-weekly visits to the study site. Sample sizes were variable, as the number of scats encountered was affected by the number of animals ashore, which varied throughout the year. Only fresh scats were collected. Each scat was placed separately in a plastic bag, labelled with the date of collection, and returned to the laboratory for processing.

In the laboratory, each scat was washed through a $0.5 \mathrm{~mm}$ sieve under running water to collect the undigested prey remains. Signs of seabirds (penguins) in the diet were noted, but no attempt was made to identify and quantify the prey. For fish and cephalopods, the sagittal otoliths and lower beaks, respectively, were used for identification and quantification of prey, and for crustaceans, the carapace was used. The prey remains were identified to the lowest possible taxonomic level using identification manuals (Clarke 1986; Hecht 1987; Australian National Antarctic Research Manual 1990; Smale et al. 1993, 1995; Reid 1996) or comparison with a reference specimen collection (Port Elizabeth Museum at Bayworld), and counted.

Prey remains that could not be identified because they were broken or too eroded were discarded. Those that could be identified were enumerated for each taxonomic group. The numerical abundance (NA) of each taxonomic group was determined for each sampling date, month, season (defined below), year and the entire study period. No attempt was made to sort otoliths into left from right; rather it was assumed that the numbers of fish consumed were represented by the numbers of otoliths found in scats. The frequency of occurrence (FO) of each taxonomic group, the number of scats collected in a sampling date, month, season, year or the entire study period in which a given taxonomic group was represented, was also determined.

The lengths of otolith specimens (OL) judged to be in an intact or near intact condition, were measured using a Zeiss dissecting microscope fitted with graticules following Klages and Bester (1998). The length (standard length) and mass of individual prey were estimated from the OL of pristine specimens, using standard regression equations published in Williams and McEldowney (1990), Adams and Klages (1987), Hecht (1987) and Cherel et al. (1997). As no attempt was made to match otoliths into pairs, the prey mass was reconstituted from each individual otolith and then halved. However, the individual prey mass was not estimated for G. bolini in the absence of an appropriate regression equation. The diet composition was investigated between the years and tested between seasons, using Chi-square contingency tables. Just two seasons were defined. Summer (October to March), which corresponds with the pupping and mating season and the lactation period, and winter (April to September), during which most Antarctic fur seals are absent from the island (Kerley 1983; Bester and Bartlett 1990; Kirkman et al. 
2003). For comparisons between years, only the period from January to April was considered; the sampling effort was most consistent between years during these months, when lactating, adult females are found in the breeding colony.

\section{Results}

In all, 258 faecal samples containing identifiable undigested prey remains were collected from May 1996 to April 2000. Sample sizes of scats collected varied between sampling occasions, mainly on account of variation in seal numbers in the colony (Table 1). In terms of FO, fish was by far the most common main prey item, occurring in $96.1 \%$ of scats, followed by crustaceans and cephalopods with 2.7 and $1.2 \%$, respectively. Of 7,390 otoliths isolated from scats, 7,366 could be identified to species level. The remainder was allocated to genus or family level. Remains (feathers) from unidentified penguin species were rarely encountered.

Table 1 Sample sizes of scat collections per month between May 1996 and April 2000, at the Watertunnel Stream breeding colony, Marion Island

\begin{tabular}{|l|l|l|l|l|l|l|l|}
\hline Months & 1996 & 1997 & 1998 & $\mathbf{1 9 9 9}$ & $\mathbf{2 0 0 0}$ & Total \\
\hline January & & 9 & 11 & 10 & 6 & 36 \\
\hline February & & 8 & 7 & 1 & 5 & 21 \\
\hline March & & 7 & 10 & 22 & 4 & 43 \\
\hline \hline April & & 5 & 7 & 9 & 11 & 32 \\
\hline May & 10 & 12 & 14 & 9 & & 45 \\
\hline June & 13 & & 6 & & & 19 \\
\hline July & 8 & 4 & 1 & & & 13 \\
\hline August & & 11 & & 2 & & 13 \\
\hline September & 1 & 11 & 1 & 6 & & 18 \\
\hline October & & 4 & & 4 & & 8 \\
\hline November & & & 2 & & & 2 \\
\hline December & 6 & & & 2 & & 8 \\
\hline Total & 38 & 71 & 58 & 65 & 26 & 258 \\
\hline
\end{tabular}

\section{Diet composition}

At least 25 different prey species were identified over the study period, including 21 fish species (Table 2), a crustacean species (Nauticaris marionis) and 2 cephalopod species (Brachioteuthis risei and Octopus magnificus). 
Table 2 Percentage frequency of occurrence (FO\%) and percentage of numerical abundance (NA\%) of fish species identified from otoliths $(n=7,390)$ found in the scats $(n=248)$ sampled from A. gazella at Marion Island between May 1996 and April 2000

\begin{tabular}{|c|c|c|c|}
\hline & Prey species & FO\% & NA \% \\
\hline \multicolumn{4}{|c|}{ Myctophidae } \\
\hline 1 & Electrona antarctica & 1.61 & 0.18 \\
\hline 2 & Electrona carlsbergi* & 37.75 & 13.44 \\
\hline 3 & Electrona subaspera* & 22.09 & 9.03 \\
\hline 4 & Electrona spp. & 8.03 & 1.15 \\
\hline 5 & Gymnoscopelus bolini & 20.08 & 4.44 \\
\hline 6 & Gymnoscopelus fraseri* & 40.96 & 12.68 \\
\hline 7 & Gymnoscopelus nicholsi & 13.65 & 4.36 \\
\hline 8 & Gymnoscopelus piabilis* & 63.86 & 34.09 \\
\hline 9 & Gymnoscopelus spp. & 21.69 & 2.63 \\
\hline 10 & Krefftichthys anderssoni* & 12.85 & 7.46 \\
\hline 11 & Metelectrona ventralis* & 12.85 & 2.71 \\
\hline 12 & Protomyctophum bolini & 2.81 & 0.50 \\
\hline 13 & Protomyctophum choriodon & 19.68 & 4.32 \\
\hline 14 & Protomyctophum tenisoni & 2.01 & 0.20 \\
\hline \multicolumn{4}{|c|}{ Nototheniidae } \\
\hline 15 & Gabionotothern marionensis & 4.82 & 1.03 \\
\hline 16 & Dissostichus eleginoides & 1.20 & 0.20 \\
\hline 17 & Lepidonotothen larsen & 0.40 & 0.58 \\
\hline 18 & Notothenia spp. & 1.20 & 0.05 \\
\hline 19 & Paranotothenia magellanica & 1.61 & 0.24 \\
\hline \multicolumn{4}{|c|}{ Paralepididae } \\
\hline \multirow[t]{2}{*}{20} & Magnisudis prionosa & 0.80 & 0.11 \\
\hline & Gempylidae & & \\
\hline \multirow[t]{2}{*}{21} & Paradiplospinus gracillis & 0.40 & 0.01 \\
\hline & Microstomatidae & & \\
\hline \multirow[t]{2}{*}{22} & Nansenia antarctica & 0.40 & 0.09 \\
\hline & Notosudidae & & \\
\hline 23 & Scopelareus ahlstromi & 0.80 & 0.19 \\
\hline 24 & Unidentified otoliths & 4.82 & 0.32 \\
\hline
\end{tabular}


* These species contributed most significantly towards between-season differences in diet composition

The 21 species of fish identified stemmed from seven families. Of these, the family Myctophidae was dominant, accounting for $97 \%$ of the NA of otoliths over the study period. Notothenididae accounted for $1.9 \%$ of the NA of otoliths, and other families (Paralepididae, Microstomatidae, Gempylidae and Notosudidae) were represented in small numbers $(\leq 0.3 \%)$ only (Table 2$)$.

The most numerous and frequently occurring prey species was G. piabilis, followed by $E$. carlsbergi and $G$. fraseri (Table 2). These species were common in the diet throughout the study period and accounted for $60.21 \%$ of the NA of fish in the diet. E. subaspera, $G$. bolini, G. nicholsi, Krefftichthys anderssoni and P. choriodon together accounted for $30 \%$ of the diet in terms of NA (Table 2). The FO of fish species in the diet were strongly related to their NA in the diet (Spearman $R=0.912638 ; P<0.001$ ). Only a few species (e.g. Krefftichthys anderssoni and $P$. choriodon) did not fit into this relationship, in that they had high FO\% but low NA\%.

\section{Seasonal variation}

The composition of the diet differed significantly between seasons $\left(\chi^{2}=1853.072\right.$; $P<0.001$, Figs. 1, 2). G. piabilis and K. anderssoni dominated the diet in summer. These species were also abundant during winter (Fig. 2), though in smaller quantity. $E$.

carlsbergi, E. subaspera and G. fraseri were the most dominant fish prey in winter. There was no seasonal pattern regarding the occurrence of cephalopods or crustaceans in the diet, or in the occurrence of fish species such as Dissostichus eleginoides, G.

marionensis, Lepidonotothen larsen or G. bolini, which were rarely encountered.

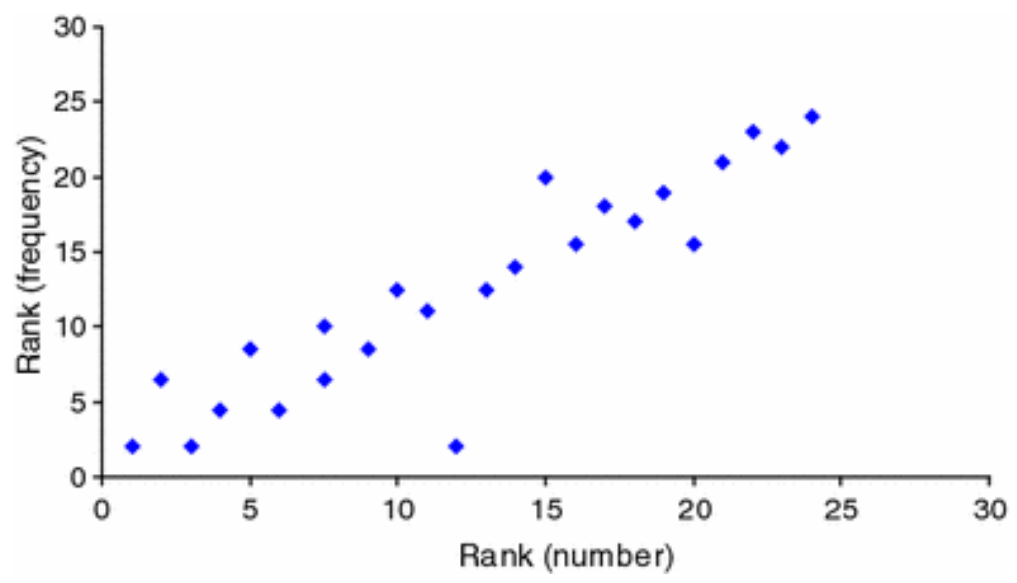

Fig. 1 Relationship between the frequency of occurrence and numerical abundance of prey species eaten by A. gazella 


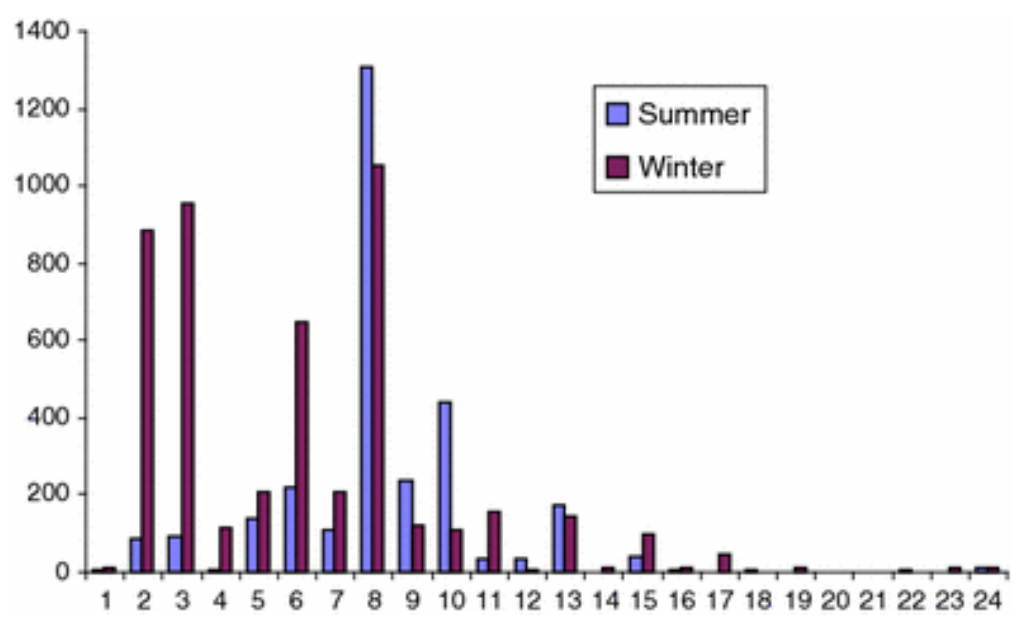

Fig. 2 Seasonal composition of prey species in the diet of A. gazella

\section{Inter-annual variation}

Cephalopods appeared in the scats of A. gazella only in 1998 and 1999, and in low numbers (mean NA of 0.14 and 0.01 , respectively). Crustaceans were only found in the scats in 1999 (mean NA of 0.17), while fish appeared in large quantities in the scats in all the years. Myctophids dominated the diet throughout the study, with G. piabilis by far the most numerous prey species every year from 1996 to 2000, followed by G. fraseri. Of the remaining species, those that occurred most frequently in the scats throughout the study period include E. carlsbergi, E. subaspera, G. bolini, K. anderssoni, M. ventralis and $P$. choriodon. Few Notothenia spp. were observed in the scats, only D. eleginoides (1997 and 1998), P. magellanica and L. larsen (1999) occurred during some years, while $G$. marionensis appeared sporadically from 1996 to 2000.

\section{Size and mass classes of fish consumed}

The estimated length-frequency distributions of fish species encountered and consumed varied considerably (Table 3). P. magellanica, L. larsen and D. eleginoides (Table 3), were the largest fish eaten in terms of size and mass, but featured negligibly in the diet (Table 2). The majority of G. piabilis were in the size range $125-153 \mathrm{~mm}$, with a mean standard length of $137 \mathrm{~mm}$. This species was an important constituent of the diet in terms of mass $(77 \%$, mean mass $=31.17 \mathrm{~g})$. Comparison of the mass selectivity of this species in the diet with regard to the broad range of sizes available suggests that A. gazella tend to prefer larger prey items (Table 3), in this case mature G. piabilis close to their maximum size of about $146 \mathrm{~cm}$. Other smaller prey groups, which were much less prevalent in the diet in terms of relative mass included E. carlsbergi, E. subaspera and $K$. anderssoni (Table 3 ). 
Table 3 Summary of standard lengths ( $\mathrm{mm}$ ) and mass (g) of fish prey, as reconstituted from the OL of otoliths found in scats

\begin{tabular}{|c|c|c|c|c|c|c|}
\hline \multicolumn{4}{|l|}{ Standard length (mm) } & \multicolumn{3}{|c|}{ Standard mass (g) } \\
\hline Prey species & Mean & SD & Range & Mean & SD & Range \\
\hline Dissostichus eleginoides & 242.51 & 74.42 & $\begin{array}{l}140.41- \\
319.08\end{array}$ & 225.20 & 166.25 & $32.03-438.28$ \\
\hline Electrona antarctica & 79.38 & 17.11 & $55.61-103.56$ & 7.66 & 4.6254 & $2.26-15.34$ \\
\hline Electrona carlsbergi & 68.86 & 10.03 & $43.61-100.20$ & 5.991 & 2.4707 & $1.63-15.91$ \\
\hline Electrona subaspera & 82.883 & 11.4572 & $58.62-111.24$ & 11.221 & 4.8769 & $3.48-26.89$ \\
\hline Metelectrona ventralis & 99.70 & 7.62 & $66.66-100.20$ & 8.97 & 2.3996 & $5.22-15.91$ \\
\hline Gymnoscopelus bolini & 118.95 & 22.444 & $82.09-196.82$ & - & - & - \\
\hline Gymnoscopelus nicholsi & 115.92 & 26.618 & $60.24-109.30$ & 21.2 & 12.55 & $2.41-15.29$ \\
\hline Gymnoscopelus fraseri & 84.096 & 7.4535 & $60.24-165.23$ & 6.9551 & 1.8639 & $2.41-15.29$ \\
\hline Gymnoscopelus piabilis & 137.05 & 9.48632 & $85.33-165.23$ & 31.168 & 6.1637 & $7.158-54.57$ \\
\hline Krefftichthys anderssoni & 42.468 & 5.78185 & $21.71-57.31$ & 0.7974 & 0.3166 & $0.08-2.01$ \\
\hline Protomyctophum bolini & 43.13 & - & - & 1.10 & - & - \\
\hline $\begin{array}{l}\text { Protomyctophum } \\
\text { choriodon }\end{array}$ & 78.77 & 12.83 & $33.76-103.39$ & 3.76 & 1.9015 & $0.47-9.68$ \\
\hline Protomyctophum tenisoni & 79.36 & 3.13 & $74.74-83.36$ & 7.609 & 0.9138 & $6.29-8.82$ \\
\hline Lepidonotothen larsen & 124.34 & 4.41 & $\begin{array}{l}119.53- \\
128.19\end{array}$ & 0.89 & 0.0562 & $0.83-0.94$ \\
\hline $\begin{array}{l}\text { Paranotothenia } \\
\text { magellanica }\end{array}$ & 250.09 & 60.65 & $\begin{array}{l}193.27- \\
3711.55\end{array}$ & 399.01 & 335.8 & $\begin{array}{l}158.10- \\
1123.30\end{array}$ \\
\hline $\begin{array}{l}\text { Gabionotothern } \\
\text { marionensis }\end{array}$ & 99.489 & 26.2305 & $64.63-145.96$ & 9.9442 & 9.1684 & $65.74-159.69$ \\
\hline
\end{tabular}

\section{Discussion}

\section{Diet composition}

The diet of A. gazella at Marion Island is predominated by fish, as has been shown to be the case at Macquarie Island (Goldsworthy et al. 1997), Heard Island (e.g. Green et al. 1997) and Iles Kerguelen (Cherel et al. 1997). By contrast, krill (Euphausia superba) is the most dominant prey species in the diet of this fur seal at South Georgia (e.g. North et al. 1983; Doidge and Croxall 1985; Boyd et al. 1991; Reid 1995; Reid and Arnould 1996) and Bouvet Island (Kirkman et al. 2000). No krill was identified in the diet of A. gazella at Marion Island, the endemic $N$. marionis, which occurs exclusively over a narrow shelf area in the proximity of the island (Branch et al. 1991), was the only crustacean in the diet. 
The majority of fish prey taken around Marion Island were mesopelagic myctophids (Electrona spp., Gymnoscopelus spp., Protomyctophum spp. and Krefftichthys spp.), which are characteristic of deep, offshelf water and can be found in the deep scattering layers, usually at 200-500 m, although G. nicholsi can also be found near the bottom of the shelf (Green et al. 1997). G. piabilis was by far the most abundant prey species in the diet, as has been shown to be the case with A. tropicalis both at Marion Island (Klages and Bester 1998) and Macquarie Island (Goldsworthy et al. 1997). G. piabilis, together with E. carlsbergi and G. fraseri, constituted the most abundant prey groups in the diet. The low presence of $P$. choriodon, as well as the absence of Champsocephalus gunnari, numerically the most abundant fish taxa in the diet of A. gazella at South Georgia (Reid and Arnould 1996), may be related to the overwhelming abundance of other prey species around Marion Island (Klages and Bester 1998). However, it appears characteristic that at localities where the shelf is wide (e.g. Heard Island, Iles Kerguelen), benthic fish such as notothenids and skates are more important in the diet than at localities with a narrow shelf area (e.g. Macquarie Island, Marion Island), where myctophids dominate the diet (Klages and Bester 1998). The fact that species generally found closer inshore, such as $C$. gunnari and D. eleginoides, were absent from the diet at Marion Island, suggests that $A$. gazella feed further offshore (Klages and Bester 1998; Goldsworthy et al. 1997; Green 1997).

Only a few cephalopods were identified in the diet of the Antarctic fur seals at Marion Island (this study). Cephalopods seem to be taken opportunistically, as suggested by Kirkman et al. (2000), for the Bouvet population of A. gazella. As cephalopod beaks are likely to accumulate in the stomachs of marine predators (Reid 1995; Klages and Bester 1998) or to have been ejected by vomiting (Kirkman et al. 2000), they may not appear in scats on a regular basis. However, cephalopod remains are frequently present in scats of Antarctic fur seals at other sites (Green et al. 1991; Daneri et al. 1999) and therefore it follows that they are probably of little importance in the diet at Marion Island.

At Marion Island; predation of king penguins (Aptenodytes patagonicus), macaroni penguins (Eudyptes chrysolophus) and less commonly rockhopper penguins ( $E$. chrysocome) by A. gazella has been observed (Hofmeyr and Bester 1993; unpublished data). However, scats collected in this study hardly ever contained penguin remains (feathers). This may be because the seal-seabird predation events at the island are concentrated at large seabird breeding colonies, and the predators, which tend to be subadult or adult males (Hofmeyr and Bester 1993), will not necessarily haul out at the Watertunnel Stream seal colony, at least $5 \mathrm{~km}$ distant from the nearest location with major king and macaroni penguin colonies (Goodhope Bay).

\section{Seasonal variation}

Similar to this study, highly seasonal patterns in the consumption of fish species, particularly of myctophids, have been documented for A. gazella at Heard Island (Green et al. 1989), South Georgia (Reid and Arnould 1996) and previously at Marion Island (Klages and Bester 1998). Such patterns may depend on seasonal differences in the availability of prey species (Lea et al. 2002b). As for other sites, Heard Island and South 
Georgia, there was no discernable seasonal pattern in the intake of cephalopods (Green et al. 1989; Reid 1995; Reid and Arnould 1996; Cherel et al. 1997).

Based on the seasonal haulout behaviour and numbers of the fur seals (Kerley 1983), mostly lactating females would have deposited scats at Watertunnel Stream from December to April/May each year; between the period when pups are weaned and November, mainly subadults and adult males are present. The seasonal variation in the sex-age classes of A. gazella would likely have contributed to the strong seasonal variation in diet composition. However, judging from the behavioural patterns of the sympatric A. tropicalis, it may be that the prey species, which are preferred during summer (e.g. G. piabilis and K. anderssoni), are much less accessible during winter. A. tropicalis have a much longer lactation period than A. gazella and nurse their pups throughout the winter. They make significantly longer feeding trips during winter than in summer (Kirkman et al. 2002), suggesting that suitable prey is to be found much further from the island during winter (Green 1997; Kirkman et al. 2002; Lea et al. 2002a). Animals returning to the island from distant foraging grounds during winter would undoubtedly defecate at sea, leading to an inherent bias in the recovery of hard prey remains (Naya et al. 2002; Staniland 2002).

\section{Inter-annual variation}

The finding that G. piabilis followed by E. carlsberg are the main prey of A. gazella (in terms of both abundance and biomass) differs from the findings of a previous (19891995) study by Klages and Bester (1998), which showed P. tenision to be overwhelmingly dominant in terms of abundance, with $G$. piabilis a distant second. Other prey species (E. carlsbergi, E. subaspera, G. nicholsi, L. larsen, P. magellanica and K. anderssoni) contributed less or were completely absent in some years during both this and the previous study; fluctuations in the intake of these species may be related to effects of environmental factors on their availability (Lutjeharms 1990), or else to the relative availability of the more important prey species. The appearance of crustaceans (N. marionis) in the diet during the breeding season in 1999 (this study) suggests that they may have fed closer to the shore during that year. $N$. marionis occur exclusively on the shelf area and were not recorded in the diet of A. gazella, or A. tropicalis for that matter, at any other time between 1989 and 2001 (Klages and Bester 1998; this study). However, this may have been an artefact of the sampling in that scats dominated by crustaceans in any year may not have been recognised as A. gazella scats and went uncollected.

\section{Sizes and mass of prey consumed}

The estimated size and mass classes of the fish species consumed by A. gazella in this study (2.71-37.16 cm and $<1$ to $438.28 \mathrm{~g}$ ) was similar to that found for the period 19891995 (Klages and Bester 1998), although the average prey was slightly smaller in the previous study. The size range of prey taken by A. gazella at Marion Island was relatively narrow compared to that found at South Georgia (Reid and Arnould 1996) and Heard Island (Green et al. 1997). This is on account of the occurrence of large prey such as $C$. gunnari in the diet at the latter locations, whereas Paranotothenia magellanica and $G$. piabilis were the largest prey found in the scats at Marion Island. 


\section{References}

Adams N, Klages NT (1987) Seasonal variation in the diet of king penguin (Aptenodytes patagonicus) at sub-Antarctic Marion Island. J Zool, Lond 212:303-324

Bester MN, Bartlett PA (1990) Attendance behaviour of Antarctic and subantarctic fur seal females at Marion Island. Antarct Sci 2:309-312

Bonner WN (1968) The fur seal of South Georgia. Sci Rep Br Antarct Surv 5:17-24

Boyd IL, Lunn NJ, Barton T (1991) Time budgets and foraging characteristics of lactating Antarctic fur seals. J Anim Ecol 60:577-592

Branch ML, Griffiths CL, Kensley B, Sieg J (1991) The benthic crustacea of the subAntarctic Marion and Prince Edward Islands: illustrated keys to the species and results of the 1982-1989 University of Cape Town surveys. S Afr J Antarct Res 21:35

Casaux R, Baron A, Carlini A (1998) The diet of the Antarctic fur seal Arctocephalus gazella at Harmony Point, Nelson Island, South Shetland Islands. Polar Biol 20:424-428

Casaux R, Baron A, Ramón A (2003) Diet of Antarctic fur seals Arctocephalus gazella at the Danco Coast, Antarctic Peninsula. Polar Biol 26:49-54

Cherel Y, Guinet C, Tremblay Y (1997) Fish prey of Antarctic fur seals Arctocephalus gazella at lle de Croy, Kerguelen. Polar Biol 17:87-90

Clarke MR (1986) A handbook for the identification of cephalopod beaks. Clarendon, Oxford

Condy PR (1978) Distribution, abundance and annual cycle of fur seals (Arctocephalus spp.) on the Prince Edward Islands. S Afr J Wildl Res 8:159 -168

Condy PR (1981) Annual food consumption, and seasonal fluctuations in biomass of seals at Marion Island. Mammalia 45:21-30

Croxall JP, Pilcher MN (1984) Characteristics of krill Euphausia superba eaten by Antarctic fur seals Arctocephalus gazella at South Georgia. Br Antarct Surv Bull 63:117125 
Daneri GA (1996) Fish diet of the Antarctic fur seal, Arctocephalus gazella, in summer, at Stranger Point, King George Island, South Shetland Islands. Polar Biol 16:353-355

Daneri GA, Coria NR (1992) The diet of Antarctic fur seals, Arctocephalus gazella, during the summer-autumn period at Mossman Peninsula, Laurie Island (South Orkneys). Polar Biol 11:565-566

Daneri GA, Coria NR (1993) Fish prey of Antarctic fur seals, Arctocephalus gazella, during the summer-autumn period at Laurie Island, South Orkney Islands. Polar Biol $13: 287-289$

Daneri GA, Carlini AR (1999) Spring and summer predation on fish by the Antarctic fur seal, Arctocephalus gazella, at King George Island, South Shetland Islands. Can J Zool 77:1157-1160

Daneri GA, Piatkowski U, Coria NR, Carlini AR (1999) Predation on cephalopods by Antarctic fur seals, Arctocephalus gazella, at two localities of the Scotia Arc, Antarctica. Polar Biol 21:59-63

Dellinger T, Trillmich F (1988) Estimating diet composition from scat analysis in otariid seals (Otariidae): is it reliable? Can J Zool 66:1865-1870

Doidge DW, Croxall JP (1985) Diet and energy budget of the Antarctic fur seal Arctocephalus gazella at South Georgia. In: Siegfried WR, Condy PR, Laws RM (eds) Antarctic nutrient cycles and food webs. Proceedings of the 4th SCAR symposium on Antarctic biology. Springer, Berlin, pp 543-550

Goldsworthy SD, Hindell MA, Crowley HM (1997) Diet and diving behaviour of sympatric fur seals Arctocephalus gazella and Arctocephalus tropicalis at Macquarie Island. In: Hindell MA, Kemper C (eds) Marine mammal research in the southern hemisphere: status, ecology and medicine. Surrey Beatty, Sydney, pp 151-163

Goldsworthy SD (1999) Maternal attendance behaviour of sympatrically breeding Antarctic and subAntarctic fur seals, Arctocephalus spp., at Macquarie Island. Polar Biol $21: 316-325$

Green K (1997) Diving behaviour of Antarctic fur seals Arctocephalus gazella Peters around Heard Island. In: Hindell MA, Kemper C (eds) Marine mammal research in the southern hemisphere: status, ecology and medicine. Surrey Beatty, Sydney, pp 97-104

Green K, Burton HR, Williams R (1989) The diet of Antarctic fur seals Arctocephalus gazella (Peters) during the breeding season at Heard Island. Antarct Sci 1:317-324 
Green K, Williams R, Burton HR (1991) The diet of Antarctic fur seals during the late autumn and early winter around Heard Island. Antarct Sci 3:359-361

Green K, Williams R, Burton HR (1997) Foraging ecology of Antarctic fur seals Arctocephalus gazella Peters around Heard Island. In: Hindell MA, Kemper C (eds) Marine mammal research in the southern hemisphere: status, ecology and medicine. Surrey Beatty, Sydney, pp 105-113

Guinet C, Jouventin P, Georges JY (1994) Long-term population changes of fur seals Arctocephalus gazella and Arctocephalus tropicalis on subantarctic (Crozet) and subtropical (St Paul and Amsterdam) islands and their possible relationship to El Niño southern oscillation. Antarct Sci 6:473-478

Hecht T (1987) A guide to the otoliths of the Southern Ocean fishes. S Afr J Antarct Res $17: 1-87$

Hofmeyr GJG, Bester MN (1993) Predation on king penguins by Antarctic fur seals. S Afr J Antarct Res 23:71-74

Hofmeyr GJG, Bester MN, Jonker FC (1997) Changes in population size and distribution of fur seals at Marion Island. Polar Biol 17:150-158

Kerley GIH (1983) Comparison of seasonal haulout patterns of fur seals Arctocephalus tropicalis and A. gazella at the Prince Edward Islands, Southern Ocean. S Afr J Zool 18:388-392

Kirkman SP, Wilson W, Klages NTW, Bester MN, Isaksen K (2000) Diet and estimated food consumption of Antarctic fur seals at Bouvetøya during summer. Polar Biol 23:745752

Kirkman SP, Bester MN, Hofmeyr GJG, Pistorius PA, Makhado AB (2002) Pup growth and maternal attendance patterns in subantarctic fur seals. Afr Zool 37:13-19

Kirkman S.P., Bester M.N., Makhado A.B., Pistorius P.A. 2003. Female attendance behaviour of Antarctic fur seals at Marion Island. Afr Zool 38: 402-405

Klages NTW, Bester MN (1998) Fish prey of fur seals Arctocephalus spp. at subantarctic Marion Island. Mar Biol 131:559-566

Klages NTW, Hofmeyr GJG, Gjertz I (1999) Prey of Antarctic fur seals at Bouvet Island, 
Southern Ocean. Polar Rec July: 255-257

Lea M-A, Cherel Y, Guinet C, Nicholls PD (2002a) Antarctic fur seals foraging in the Polar Frontal Zone: inter-annual shifts in diet as shown from faecal and fatty acid analyses. Mar Ecol Prog Ser 245:281-297

Lea M-A, Hindell M, Guinet C, Goldsworthy S (2002b) Variability in the diving activity of Antarctic fur seals, Arctocephalus gazella, at Iles Kerguelen. Polar Biol 25:269-279

Lutjeharms JRE (1990) Temperatuurstruktuur van die oseaanbolaag tussen Kaapstad en Marion-eiland. S Afr J Zool 20:21-32

Naya DE, Arim M, Vargas R (2002) Diet of South American fur seals (Arctocephalus australis) in Isla de Lobos, Uruguay. Mar Mamm Sci 18:734-745

Nel DC, Ryan PG, Nel JL, Klages NTW, Wilson RP, Robertson G, Tuck GN (2002) Foraging interactions between wandering albatrosses Diomedea exulans breeding on Marion Island and long-line fisheries in the Southern Indian Ocean. Ibis 144:141-154

North AW (1996) Fish in the diet of Antarctic fur seals Arctocephalus gazella at South Georgia during winter and spring. Antarct Sci 8:155-160

North AW, Croxall JP, Doidge DW (1983) Fish prey of the Antarctic fur seals Arctocephalus gazella at South Georgia. Br Antarct Surv Bull 61:27-37

Osman LP, Hucke-Gaete R, Moreno CA, Torres D (2004) Feeding ecology of Antarctic fur seals at Cape Shirreff, South Shetlands, Antarctica. Polar Biol 27: 92-98

Pierce GJ, Boyle PR (1991) Review of methods for diet analysis in piscivorous marine mammals. Oceanogr Mar Biol Ann Rev 29:409-486

Pierce GJ, Boyle PR, Diack JSW (1991) Identification of fish otoliths and bones in faeces and digestive tracts of seals. J Zool 224:320-328

Reid K (1995) The diet of Antarctic fur seals (Arctocephalus gazella Peters 1875) during winter at South Georgia. Antarct Sci 7:241-249

Reid K (1996) A guide to the use of otoliths in the study of predators at South Georgia. British Antarctic Survey, Cambridge

Reid K, Arnould PY (1996) The diet of Antarctic fur seals Arctocephalus gazella during 
the breeding season at South Georgia. Polar Biol 16:105-114

Smale MJ, Clarke MR, Klages NTW, Roeleveld MAC (1993) Octopod beak identification-resolution at a regional level (Cephalopoda, Octopoda: Southern Africa). S Afr J Mar Sci 13:269-293

Smale JM, Watson G, Hecht T (1995) Otolith atlas of Southern African marine fishes. Ichthyological Monographs No.1. JLB Smith Institute of Ichthyology, Grahamstown, South Africa

Staniland IJ (2002) Investigating the biases in the use of hard prey remains to identify diet composition using Antarctic fur seals (Arctocephalus gazella) in captive feeding trials. Mar Mamm Sci 18.1:223-243

Wilkinson IS, Bester MN (1990) Continued population increase in fur seals, Arctocephalus tropicalis and A. gazella, at the Prince Edward Islands. S Afr J Antarct Res 20:58-63

Williams R, McEldowney A (1990) ANARE research notes 75: a guide to the fish otoliths from waters off the Australian Antarctic Territory, Heard and Macquarie Islands. ANARE Res Notes 75:1-169 